\title{
An Experimental Study of L2 Acquisition of Mandarin Unaccusative Verbs by English-Speaking Learners
}

\author{
Catherine Shee Hei Wong \\ School of Education and Languages, The Open University of Hong Kong \\ Email: cshwong@ouhk.edu.hk
}

\begin{abstract}
The present study investigates the acquisition of Chinese Mandarin unacussative verbs by English-speaking L2 leaners of Chinese, in light of Universal Grammar and Interlanguage (IL) phenomenon. The results of the experiment show that there is no strong evidence for the overpassivization of Mandarin unaccusative verbs, which calls into question the claim that the overpassivization phenomenon of unaccusative verbs is universal in second language acquisition (SLA). The L2 learners in our experiment performed better with non-alternating unaccusative verbs than alternating unaccusative verbs, which might suggest that learners were probably treating the alternating unaccusative verbs in our experiment as underlyingly transitive and thus accepted the ungrammatical passivized unaccusative verbs in the Grammaticality Judgement task. This phenomenon is consistent with child's L1 development. We attribute the overpassivization of the Chinese unaccusative verbs in our experiment to the hypothesis of non-target lexical causativization as in L2 acquisition of English.
\end{abstract}

Keywords: Mandarin unaccusative verbs, universal grammar, interlanguage, overpassivization, SLA

\section{Introduction}

Passivization displays a complex syntactic phenomenon in different languages. The Mandarin bei (被) construction is debatable: Some argue it is a passive, involving movement (Koopman, 1984; Travis, 1984), but others reason it is a biclausal structure (Hashimoto, 1987; Huang, 1999; Wei, 1994). It is also found that a typical L2 error of Chinese L2 learners of English ergative structure is the overgeneralization of passives to ergative structure (e.g., Balcom, 1997; Ju, 2000; Kong, 2018; Su, 2008; Yip, 1995; Zobl, 1989, etc.). This overpassivization phenomenon, which is not restricted to any particular L1 group (e.g., Kondo, 2005; Mathieson, 2017; Simargool, 2006), may thus suggest that the errors are language universal rather than language specific. However, this cannot be proved as L2 universal, unless we can observe the same phenomenon occurring in the reverse direction. This study examines the extent of overpassivization of unaccusative verbs in SLA by investigating the acquisition of Chinese Mandarin unacussative verbs by English-speaking L2 leaners of Chinese.

\subsection{Previous Research on Overpassivization of Unaccusatives in SLA}

Many SLA researchers have noted that L2 learners of English appear to overextend passive structure to a class of intransitive verbs known as unaccusative verbs, which was first identified by Perlmutter (1978) in the Relational Grammar framework. Pelmutter proposed the Unaccusative Hypothesis, which claims that the class of intransitive verbs is not homogeneous but consists of two subclasses - unaccusative verbs (e.g., appear, fall, happen, sink, roll) and unergative verbs (e.g., walk, talk, sing). Semantically, they can be differentiated in that the subject of an unaccusative verb does not actively intiate or is not actively responsible for the action of the verb but bears the semantic role of theme or patient that is usually associated with the object. Most change-of-state verbs fall into that category. However, unaccusative verbs also share syntactic features that set them apart from unergative verbs. Burzio (1986) integrated what Perlmutter had named unaccusative verbs into Government and Binding theory and renamed them ergative verbs.

Moreover, it is shown that even highly advanced L2 learners of English overpassivized unaccusative verbs (e.g., Kong, 2018; Ju, 1997; Kondo, 2005; Mathieson, 2017; Su, 2008; Yip, 1995; Zobl, 1989). The 
findings show that most L2 learners of English regardless of their L1 background had difficulty in acquiring the unaccusative verbs, even when they have reached the advanced level. The overpassivization phenomenon, which is not restricted to any particular L1 group, may thus suggest that the errors are a universal rather than language specific phenomenon. However, this phenomenon cannot be considered as a universal phenomenon in L2, unless we can observe the same phenomenon occurring in the reverse direction. In the present study, English-speaking L2 leaners of Chinese were the subjects of our experiment. As unaccusative verbs are used in Chinese and English in the active form, the claim that the overpassivization phenomenon is L2 universal predicts that English-speaking L2 leaners of Chinese would also exhibit the tendency to either resist accepting unaccusative verbs as grammatical in the active or to passivize them.

One of the important findings in these SLA studies is that learners of English only used passive morphology with unaccusatives but not unergatives though both classes are intransitive. Zobl (1989) was the first to discuss L2 learners' acquisition of split intransitivity (i.e., properties of unaccusative and unergative verbs). He discusses the inappropriate morphology (be and the past participle en) in the English composition of L2 Japanese learners, linking its occurrence to the class of unaccusative verbs and proposing that learners subsume unaccusatives under the syntactic rule for passive formation. Research by Yip (1995) and Balcom (1997) suggest a similar pattern of results to those of Zobl (1989). Chinese learners of English seem to use passive morphology as a way of marking a theme in subject position with unaccusative verbs but not with unergative verbs.

Kondo (2005) explores the question of whether L2 learners of English with typologically different L1s such as Japanese and Spanish will overgeneralize passive morphology to unaccusative verbs. The results of his study indicate that both Japanese and Spanish learners of English differentiate unaccusatives from unergatives. However, the two groups differ in their treatment of unaccusatives with transitive alternants and intransitive alternants, suggesting influence of the morphological properties of the L1. Su (2008) addresses the overpassivization errors in Chinese-speaking learners' acquisition of English as a learnability problem connected with L1 and L2 acquisition of argument structure. It is found that the learners passivized unaccusatives to a greater extent than non-alternating unaccusatives, and they demonstrated inaccessibility to the semantic meaning of unaccusatives and the unaccusative construction in their L1. Mathieson (2017) studies the use and misuse of English passive voice in EFL writing by Japanese-speaking learners. He argues that many Japanese EFL learners struggle with agentless passives in English due to L1 transfer, which results in the incorrect iteration and fossilization of novel passive constructions. Kong (2018) validates the proposals made by Yip (1995) and Balcom (1997), suggesting that the Chinese-speaking learners in his study overgeneralize passive morphology to unaccusative verbs in L2 English. The results of Kong's (2018) study also show that it is difficulty for the learners to establish native-like syntactic realization of unergative verbs in their L2 English and some of them treated unergative verbs as transitive verbs. Kong (2018) proposes two factors for the learners' low accuracy on unergative verbs: (1) Case assignment, and (2) the absence of positive evidence that unergative $+\mathrm{NP}$ construction is not allowed in English.

To conclude, some linguists attribute the overgeneralization of passives to ergative structure L2 learners of English to L1 influence, some attribute it to learners not distinguishing between transitive and unaccusative verbs, and others attribute it to the absence of an agent or the presence of a theme object (Simargool, 2006).

\subsection{Research Question}

Given the findings in the previous research, the research question especially designed for our study to investigate the extent of overpassivization of unaccusative verbs in SLA is: Do L2 learners show a tendency to overpassivize unaccusative verbs in their Chinese IL grammar?

\section{Unaccusative Verbs in Chinese and English}

It was Pelmutter (1978) who first proposed an Unaccusative Hypothesis, which claims that the class of intransitive verbs consists of two subclasses - unaccusatives (e.g., appear, fall, happen, break, melt) and unergatives (e.g., walk, talk, sing). Semantically, they can be differentiated in that the subject of an 
accusative verbs does not actively initiate or is not actively responsible for the action encoded by the verb but bears the semantic role of theme or patient that originates in object position at D-structure. Most change-of-state verbs fall into that category. Unergatives, on the other hand, take subjects that the role of agent which is based-generated in the subject position at D-structure.

Note that there are two types of unaccusatives - alternating (those with transitive counterparts) and non-alternating (those without transitive counterparts). The alternating unaccusative verbs that are most commonly associated with overpassivization include verbs such as increase, decrease, improve, change, grow, continue, and break, and the non-alternating unaccusative verbs include verbs such as die, suffer, happen, arrive, appear, disappear, and vanish.

Oshita (1995), following Levin \& Rappaport Hovav (1995), draws a distinction between unaccusative verbs and ergative verbs on the grounds of an existing or non-exiting transitive alternant. Thus, in his account, verbs like sink, break and open would be unaccusative verbs, while verbs like happen, appear and die are ergative verbs. Other linguists, for example Sorace (1993), distinguish two subclasses, paired and unpaired unaccusative verbs, where paired unaccusative verbs comprises all the ergative verbs that have either a transitive or an unergative counterpart.

As claimed by Oshita (2000), the contrast between the two classes of intransitive verbs (i.e., unaccusative and unergative verbs) becomes particularly clear when they are compared with transitive verbs because the argument of unaccusative verbs exhibits the syntactic properties of the object of a transitive verb while that of unergative behaves like the subject. Along this line of analysis, the resulting different verb classes can be schematized as follows in (1):

(1)

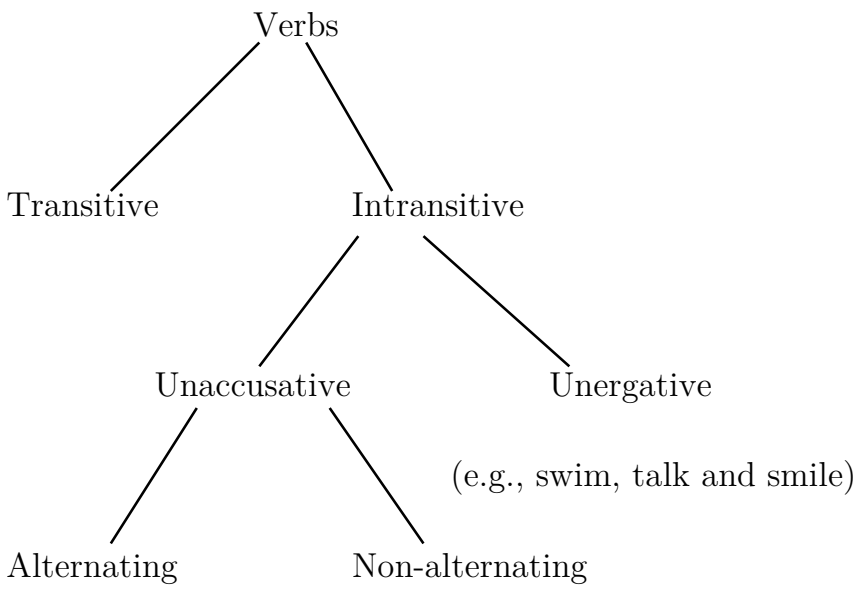

(Modified from Oshita, 2000, p.295)

As noted by Levin and Rappaport Hovav (1995), there are semantic regularities in the composition of the two classes of unaccusative verbs and unergative verbs. These semantic regularities are also manifested across languages in striking similar ways. Some languages differentiate unaccusative verbs and unergative verbs through case, morphological tense-aspect markings, or different word order (e.g., Italian and French). English, however, lacks morphosyntactic cues to distinguish unergatives from unaccusatives. In English sentences, word order does not change for unaccusatives, and there are no morphological markings that distinguish unaccusative from unergatives. These properties of English might help to explain why learners of English have difficulites with unaccusative verbs. Next, we continue with the descriptions of the structure and property of the unaccusative constructions in Chinese and English.

\subsection{Chinese Unaccusative Verbs}

Chinese has a class of unaccusative verbs with properties similar to the English unaccusative construction. Likewise, we use four sentences, (2), (3), (4) and (5) to illustrate the syntactic structures of transitive, passive, unaccusative and unergative in Chinese. The similarities and differences among these constructions will also be discussed below. 
(2) Transitive: 他改变了我的想法。

$\underline{\text { ta }}$ gaibian le wode xiangfa.

Agent Patient/Theme

he change PFV I-POSS thought

'He has changed my mind/thought.'

(3) Passive: 我的想法被（他）改变了。

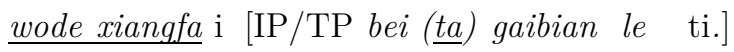

Patient/Theme Agent

I-POSS thought BEI he change PFV

'My thought was changed (by him).'

(4) Unaccusative: 我的 想法 改变了。 wode xigngfa i [vp gaibian le ti.]

Patient/Theme

I-POSS thought change PFV

'My thought has changed.'

(5) Unergative: 小明笑了。

Xiaoming [VP xiao le.]

Agent

Xiaoming smile PFV

'Xiaoming smiled.'

From the above sentences in Chinese, we notice that the Theme role is usually assigned to objects and the Agent role to subjects in (2) and (5). We note that Chinese also has alternating unaccusative verbs in (4) (those paired with a transitive/causative counterpart) as the English ones in (7) and (9). Moreover, like English passive and unaccusative structures, passive and unaccusative structures in Chinese both involve NP movement.

However, as argued by Li (1990), unlike the English counterparts, Chinese unaccusative verbs can assign accusative Case to the subcategoried object. The NP movement of the object of Chinese unaccusative verbs is optional while such movement in English is obligatory because of the Case filter (Chomsky, 1986). The object NP of Chinese unaccusative verbs can move to the subject position to receive nominative case as in (6a) or remain in the object position as in $(6 \mathrm{~b})$ :

$\begin{array}{ccccc}\text { (6a) 这场 } & \text { 雨 } & \text { 下 } & \text { 了 } & \text { 一天。 } \\ \text { zhechang } & \text { yu } & \text { xia } & \text { le } & \text { yitian } \\ \text { this-CL } & \text { rain } & \text { fall } & \text { PFV } & \text { one-day }\end{array}$

'It has been raining for a whole day.'

(6b) 今天 下 了一场 大雨。

jintian xia le yichang dayu

today fall PFV one-CL big-rain

'Today it has rained heavily.' 
Li (1990) has divided Chinese unaccusative verbs into three classes of verbs, namely, verbs denoting presence, appearance and disappearance and motion. Some of these unaccusative verbs are presented as follows:

a. Presence: 有 you 'have', 站 zhan 'stand', 坐 zuo 'sit', 躺 tang 'lie', 挂 gua 'hang', 放 fang 'place', etc.

b. Appearance: 来 lai 'come', 出 chu 'come out', 起 $q i$ 'emerge', 下 xia 'fall', 进 jin 'enter', 到 dao 'arrive', etc.

c. Motion: 去 qu 'go', 死 si 'die', 跑 pao 'run', 逃 tao 'escape', 过 guo 'pass', etc.

(Cited in Yip, 1995, p. 134)

However, as discussed by Yip (1995), there are only two classes of unaccusative verbs in Chinese. One class involves verbs of change-of-state such as 死 si 'die' and 醒 xing 'wake' and the other involves verbs of posture such as 坐 zuo 'sit', 躺 tang 'lie'. Grounded in previous studies, Huang (2006) claims that all verbs in Chinese can be divided into unergative type and unaccusative type. According to Huang, transitive verbs (e.g. 打 da 'beat', 骂 ma 'scold' and 写 xie 'write') and three-place rob-type verbs (e.g. 剥 bo 'peel', 踢 ti 'kick' and 抢 qiang 'rob') are unergative verbs. Causative verbs (e.g. 开 kai 'open', 关 gua 'close', 沉 chen 'sink' and 吓 xia 'frighten') and give-type verbs (e.g. 送 song 'send' and 给 gei 'give') are unaccusative verbs. In the present study, we hypothesize that the similarities and differences among the transitive, passive and unaccusative structures in English and Chinese will raise learnability problems for the subjects in our research.

\subsection{English Unaccusative Verbs}

As mentioned above, English lacks morphosyntactic cues such as morphological markings to distinguish unergatives from unaccusatives. Sentences (7) to (10) below illustrate the syntactic structures of transitive, passive, unaccusative and unergative in English.

(7) Transitive: Mary broke the glass.

Agent Theme

(8) Passive: $\underline{\text { The glass }}$ i [was broken ti (by $\underline{\text { Mary }})]$.

Theme Agent

(9) Unaccusative: The glass i [VP broke ti].

Theme

(10) Unergative: Mary [VP cried].

Agent

From the above sentences, we notice that the Theme role is usually assigned to objects and the Agent role to subjects when the sentence has the basic structure as in (7) and (10). An unergative verb has an external argument but no internal argument as in (10) while an unaccusative verb has an internal argument but no external argument as shown in (9). Thus, the subject in (9) is derived by NP movement, however, the subject in (10) is base-generated. In languages like English, the underlying object of the unaccusative verb has to move to a case position to satisfy the Case filter (Chomsky, 1986).

Moreover, as shown by (8) and (9), passive and unaccusative structures in English share similarities in that both involve NP movement and both have patient/theme subjects. And in agentless passives, the agent is not present just as in unaccusative construction. However, as discussed by many SLA researchers (e.g., Balcom, 1997; Kong, 2018; Ju, 2000; Kondo, 2005; Mathieson, 2017; Su, 2008; Yip, 1995), in English, passives structures are different from unaccusative structures in that passive verbs remain semantically transitive even after passivization, while unaccusative verbs are semantically intransitive. Moreover, two structures are different syntactically in that the implicit argument of an 
agentless passive can be re-introduced by the optional by-phrase as in (8) and (11a), while the unaccusative/ergative verb does not permit the presence of by-phrase as shown by the contrast in (11a) and (11b):

(11a) The ship was sunk by us.

(11b) *The ship sank by us.

Furthermore, passive structures allow control into a purpose clause while unaccusative structures do not as shown in (12a) and (12b):

(12a) The ship was sunk to collect insurance.

(12b) *The ship sank to collect insurance.

In passive sentences like (12a), there is an implicit argument to function as a syntactic controller which the unaccusative sentence (12b) lacks.

\subsection{Interlanguage Problem related to Chinese Unaccusative Verbs}

As discussed previously, like English passive and unaccusative structures, passive and unaccusative structures in Chinese share similarities in that both involve NP movement and both have patient/theme subjects. As observed by many SLA researchers (e.g., Balcom, 1997; Hirakawa, 1995; Ju, 2000; Kondo, 2005; Kong, 2018; Mathieson, 2017; Oshita, 2000; Su, 2008; Yip, 1995; Zobl, 1989), L2 learners of English have difficulties acquiring unaccusative verbs and they tend to overextend passivization to unaccusative verbs in their English IL. Based on the similarities shared by unaccusative verbs in Chinese and English (both are in active voice and cannot be passivized), it is possible that the overpassivization of Chinese unaccusative verbs also occurs in the IL of Chinese learners.

\section{Methodology}

\subsection{Research Hypothesis}

The hypothesis regarding overpassivization of Chinese unaccusative verbs in the present study is as follows:

If the passivization of unaccusative verbs occurs in the acquisition of Chinese regardless of LI backgrounds, the native English speakers may produce ungrammatical bei sentences with alternating and non-alternating unaccusative verbs and / or fail to reject these sentences in the Grammaticality Judgement task. In this study, we explore whether the same phenomenon occurs in the reverse direction in the acquisition of Chinese unaccusative verbs by native speakers of English. If overpassivization of unaccusative verbs is found in learners' Chinese IL, this will be consistent with the claim that the overpassivization of unaccusative verbs is a universal phenomenon in SLA regardless of the target languages and background of learners.

\subsection{Participants}

A total of 30 adult learners of Mandarin Chinese and 15 native speakers of Mandarin Chinese participated in this study. The experimental groups consisted of 30 native speakers of English (American: $\mathrm{n}=12$, British: $\mathrm{n}=8$, Canadian: $\mathrm{n}=7$, Australian: $\mathrm{n}=2$ and New Zealander: $\mathrm{n}=1$ ) who were learning Chinese as their L2. They were enrolled in universities and language institutes in Mainland China and Hong Kong to learn Mandarin Chinese and they did not know other Chinese dialects. 
The learners were divided into 2 proficiency levels - intermediate and advanced. There are totally two experimental groups. The first group (Group 1) consisted of 15 intermediate English-speaking learners, and the second group (Group 2) 15 advanced English-speaking learners.

The learners are considered homogeneous in each level and group in terms of their Chinese proficiency. Intermediate learners were able to read simple passages in Chinese on informal topics but not formal and abstract topics. They were also able to communicate with native speakers on many topics in Chinese though their fluency is limited. Advanced learners were able to read newspapers and participate effectively and with ease in most formal and informal conversations on practical, social, professional, and abstract topics.

Homogeneity in the learners' proficiency was further ensured by two criteria: (1) the marks they scored in a Chinese language proficiency test (CPT) (see Appendix A) especially designed for the study; (2) the duration of learning Chinese. Table 1 summarizes the background of the two experimental groups.

Table 1. Backgrounds of the subjects in the experiment.

\begin{tabular}{lcccc}
\hline Subjects & $\begin{array}{l}\text { Mean age } \\
\text { (years) }\end{array}$ & $\begin{array}{l}\text { Scores in CPT (full } \\
\text { score: 25 marks) }\end{array}$ & $\begin{array}{l}\text { Duration of learning } \\
\text { Chinese as a L2 }\end{array}$ & $\begin{array}{l}\text { Mean duration of living in } \\
\text { Mandarin-speaking regions }\end{array}$ \\
\hline $\begin{array}{l}\text { Group 1 } \\
\text { Inter-Eng; } \mathrm{n}=15)\end{array}$ & 25.6 & 8 to 16 & $\sim 2.5$ years & 1.8 years \\
$\begin{array}{l}\text { Group 2 } \\
(\text { Adv-Eng; } \mathrm{n}=15)\end{array}$ & 28.3 & 17 to 25 & $>4$ years & 4.1 years \\
\hline
\end{tabular}

15 native speakers of Mandarin Chinese participated in the study as the control group. They were undergraduate students from universities in Beijing and Nanjing, China. They were exchange students of two universities in Hong Kong at the time when the experiment was conducted.

\section{$3.3 \quad$ Test Structures}

There are altogether three categories of test structures in the experiment. The categories are as follows:

Category 1: Change-of-state Unaccusative Verbs Used as Transitive verbs + Agent as in (13):

$\begin{array}{clllll}\text { (13) * 那只 } & \text { 老鼠 } & \text { 被 } & \text { 小猫 } & \text { 死 } & \text { 了。 } \\ * \text { nazhi } & \text { laoshu } & \text { bei } & \text { xiaomao } & \text { si } & \text { le. } \\ \text { that-CL } & \text { rat } & \text { BEI } & \text { kitten } & \text { die } & \text { PFV }\end{array}$

* 'That rat was died by the cat.'

Category 2: Non-alternating Unaccusative Verbs as in (14):
(14) 太阳
出来
后, 浓雾
渐渐地
(*被)
taiyang
chulai hou, nongwu jianjiande
( ${ }^{*}$ bei)
消失了。
sun
come-out after thick-fog gradually
BEI
xiaoshi le.

'The thick fog (*was) disappeared gradually when the sun came out.'

Category 3: Alternating Unaccusative Verbs as in (15):
(15) 一场 大雨
后, 那块
石头 从山上
(*被) 滚
下来
了。
yichang dayu
hou, nakuai
shitou congshanshang (*bei) gun
xialai
le.
one-CL heavy-rain after, that-CL rock from-hill-LOC BEI roll
down-come PFV

'The rock (*was) rolled down from the summit after a heavy rain.'

This paper focuses on the test structures which were designed to address the research hypothesis regarding the overpassivization phenomenon of Chinese unaccusative verbs in learners' Chinese IL regardless of learners' language background. These categories can be divided into passives with agents and those without agents. While the test structures in Category 1 are passives with agent phrases, the test structures in Category 2 and Category 3 agent-less passives. The passives with agent phrases were 
chosen in the test categories as they were thought to be more natural by native speakers of Mandarin Chinese.

\subsection{Experimental Tasks}

There were two experimental tasks - a Picture Description Production (PDP) Task and a Grammaticality Judgement (GJ) Task. A description of the design of these tasks is given below.

\subsubsection{The Picture Description (PDP) Task (see Appendix B for the design of this task)}

The elicited production task comprised 16 pictures and underneath each picture a string of Chinese characters with Pinyin was provided. The subjects were asked to complete the sentences which begin with a given NP, by describing the situations in the pictures with the words provided. Subjects were allowed to add other words if they feel necessary. Also, the subjects were asked to respond in Chinese characters or Pinyin. The 16 pictures were designed to elicit a total of 8 types of target constructions related to Chinese passives. As this paper addresses the L2 acquisition of Mandarin unaccusative verbs only, an example of the test types (i.e. Category 2 and Category 3 ) involving unaccusative verbs is given as follows:

Category 2: Non-alternating unaccusative verbs

$\begin{array}{ccllcl}\text { (16) Shàngwǔ } & \text { jiǔdiǎnshífēn } & \text { yìwài } & \text { fāshēng } & \text { le } & \text { jiāotōng } \\ \text { 上午 } & \text { 九点十分 } & \text { 意外 } & \text { 发生 } & \text { 了 } & \text { 交通 } \\ \text { (morning } & 9: 10 & \text { accident } & \text { happen/occur } & \text { PFV } & \text { traffic) }\end{array}$

交通意外

Category 3: Alternating unaccusative verbs

(17) Rónghuà hěnkuài le huì bīngqílín

融化很快了会冰淇淋

(melt quickly PFV will ice-cream)

快点吃, 冰淇淋

In this PDP task, simple vocabulary was chosen and clear pictures were drawn to cue the subjects to produce the target structures. Each test type in this production task has two different tokens respectively and the 16 pictures were randomized. The time taken to complete the task was approximately 20 minutes for each subject.

3.4.2 The Grammaticality Judgement (GJ) Task (see Appendix C for the sentences used in this task)

In the GJ task, subjects were asked to read a set of 30 sentences carefully and then make a choice about the grammaticality of the sentences on a scale ranging from -2 to 2 representing different categories of judgment. -2 represents a sentence that is clearly ungrammatical, -1 represents a sentence that is probably ungrammatical, 0 indicates that the subjects are not sure about the judgment of the sentence, 1 represents a sentence that is probably grammatical, and 2 represents that a sentence is clearly grammatical. Subjects are requested to provide corrections for the sentences which they judge to be ungrammatical. Below is an example given here to illustrate the task.

Bēizi y̌̌jīng fànghao le

1. 杯子已经 放好了

(cup already place-RST PFV)

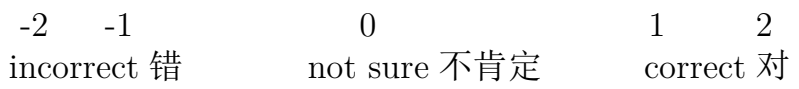

There are three categories of test structures in the GJ task (see Appendix C for all the sentences used in each type). As this paper discusses the L2 acquisition of Mandarin unaccusative verbs, an example of the test types (i.e. Categories 1, 2 and 3) involving unaccusative verbs are given as follows:

Category 1: Change-of-state unaccusative verbs - Sentences with passivized change-of-state unaccusative verb + agent, e.g., (18). 


$\begin{array}{cllll}(18) * \text { * 我 } & \text { 被 } & \text { 收音机 } & \text { 醒 } & \text { 了。 } \\ * \text { wo } & \text { bei } & \text { shouyinji } & \text { xing } & \text { le. } \\ \text { I } & \text { BEI } & \text { radio } & \text { wake } & \text { PFV }\end{array}$

'I was woken up by the radio.'

Category 2: Non-alternating unaccusative verbs - Sentences with passivized non-alternating unaccusative verb (agent-less), e.g., (19).

$\begin{array}{cllllll}(19) \text { * 等 } & \text { 了 } & \text { 很久, 小英 } & \text { 终于 } & \text { 被 } & \text { 出现 } & \text { 了。 } \\ * \text { deng lenjiu, Xiaoying zhongyu bei } & \text { chuxian le. } \\ \text { wait } & \text { PFV so-long Xiaoying finally BEI appear } & \text { PFV } \\ \text { * 'Having been waiting so long, Xiaoying was finally appeared.' }\end{array}$

Category 3: Alternating unaccusative verbs - Sentences with passivized alternating unaccusative verb (agent-less), e.g., (20).

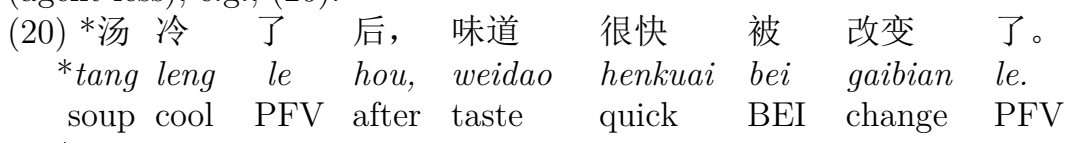

* 'The taste of the soup was changed when it cooled down.'

There are 5 tokens for each type of test structure. The number of the test sentences is then 15, and there are 15 distractors in this task. The total number of sentences amounts to 30 which were randomized. Subjects were asked to circle a number on the scale of judgment to indicate their judgment for the acceptability of a given sentence. In addition, they were asked to provide simple corrections for ungrammatical sentences or to underline the problematic part. The subjects were only required to do so if they circled $-2,-1$ or 0 . The time taken to complete the task was approximately 20 minutes for each subject.

The instructions for the two experimental tasks were given in both Chinese characters and English. One example was given in the PDP task to instruct the subjects how they should go about the task. Five examples were given on the first page of the GJ task to demonstrate the method of how the task should be done. Both tasks were presented in Chinese characters as well as Pinyin. Two versions of Chinese characters were available (for both PDP and GJ tasks), the traditional and the simplified one, depending on the specific request of each subject. It turned out that all subjects in the study knew how to read the simplified Chinese characters and used the simplified Chinese character version of the two tasks. The whole experiment, excluding the Chinese Language Proficiency Test (CPT), was self-paced, and on average the subjects took about 40 minutes to complete the PDP and GJ tasks.

\subsection{Experimental Procedure and Test Scoring}

The subjects were asked to do the PDP task first, then the CPT as an interval followed by the GJ task. In the GJ task, the subjects were asked not to go back and make changes to the previous sentences for which they had given a judgment. The sentences in the GJ were read to the subjects by the experimenter during the test. In the two experimental tasks, the subjects were given clear instructions on how to do the task. As all the sentences and phrases were presented in Chinese characters, a list of English translations for some potentially difficult words were provided. The subjects were also allowed to ask the administrator for the meanings of any unfamiliar Chinese characters and phrases. The total time to finish the whole experiment (including the CPT) was around 55 minutes for each subject.

For the scoring of the PDP task, one mark was given for a target response, zero mark for a non-target but grammatical response and minus one mark for an ungrammatical response. In the GJ task, a different scoring method from the one for the PDP task was adopted. Minus two or minus one mark was given for responses that are non-target. Minus two or minus one mark was given for a response that is non-target. No marks were given for 'not sure' responses while one or two marks were given for a correct response. The target corrections provided by the subjects for the ungrammatical ones would be considered for the scoring and taken as unequivocal evidence of their IL knowledge of Chinese passives and related structures. It is noted that subjects' responses in both the GJ task and PDP task were 
quantified, compared and measured with the responses of 13 native Mandarin speakers who served as experimental controls in our study.

There are two parts in the CPT (see Appendix A for the full version of this task): (1) a grammar test, and (2) two cloze passages. 15 multiple-choice questions were included in the grammar test. The subjects were asked to choose the best answer among the four options in each question. There are five multiple-choice questions in the first cloze passage. The subjects have to read and comprehend the passage and then circle the best answer among the four options in each question. In the other cloze passage, one Chinese word is missing in each sentence and there is a total of five missing Chinese words. The subjects were required to insert a suitable Chinese word in each blank to complete the task. The subjects were allowed to use Chinese Pinyin and were asked to complete the whole test within 15 minutes.

\section{Results of the Experiment}

\subsection{Overall Results}

In the present paper, we will report the experiment results of the test structures involving Chinese unaccusative verbs, i.e., the test sentences in Categories 1, 2 and 3. In this section, we look at the experimental results of learners from each proficiency level. We compare the similarities and differences between their results with the responses of the controls. The findings are presented in terms of the mean scores, the percentage (\%) of target responses and the percentage (\%) of some crucial types of errors in tables and bar charts. Repeated measures ANOVAs of the mean scores of the responses were also run to investigate the statistically significant differences of the test structures. Where statistically significant differences between the mean scores were found, the strictest Post-hoc Scheffe procedures were adopted to establish the source of these differences. A significant level of $p<0.05$ is assumed throughout the experiment.

\subsubsection{The Picture Description Production (PDP) Task}

The responses of the subjects and the controls were scored in terms of deviations from the target structures for each test type. Mean scores were calculated by types and the ultimate scores of target responses and some crucial types of errors would be presented in percentages. The subjects' responses were also compared with those of the controls by ANOVA. As mentioned previously, the sentence structures in Category 2 and Category 3 tested whether learners have the tendency to passivize Chinese unaccusative verbs.

As for the non-alternating and alternating unaccusative verbs in Category 2 and Category 3 in the PDP task, Table 2 presents the results of the two experimental groups (both English-speaking intermediate and advanced learners of Chinese) and the control group, the mean scores, the $\%$ of the errors and the $\%$ of target responses.

Table 2. Mean score (MS) of responses, \% of bei-passives and \% of target responses (TR) for the test structures in Category 2 (Non-alternating unaccusative verbs) and Category 3 (Alternating unaccusative verbs) in the PDP task

\begin{tabular}{lccccccccc}
\hline Category & \multicolumn{3}{c}{ Group 1 (Inter-Eng) } & \multicolumn{2}{c}{ Group 2 (Adv-Eng) } & \multicolumn{2}{c}{ Group 3 (native Chinese) } \\
& MS & \% of bei & \% of TR & MS & \% of bei & \% of TR & MS & \% of bei & \% of TR \\
\hline $\begin{array}{l}\text { 2:Non-alternating } \\
\text { unaccusative verbs }\end{array}$ & 0.88 & 0 & 88.5 & 0.96 & 0 & 96.2 & 1 & 0 & 100 \\
$\begin{array}{l}\text { 3:Alternating } \\
\text { unaccusative verbs }\end{array}$ & 0.92 & 0 & 96.2 & 0.98 & 0 & 98.1 & 1 & 0 & 100 \\
\hline
\end{tabular}

As can be seen from Table 2 above, the subjects in both intermediate and advanced levels showed native-like performance for the non-alternating unaccusative type (intermediate-level subjects: $88.5 \%$ and advanced-level subjects: $96.2 \%$ target responses). 
However, the subjects in general produced fewer target responses for the alternating unaccusative verbs (intermediate-level subjects: $96.2 \%$ and advanced-level subjects: $98.1 \%$ target responses). However, there were no errors, i.e., the use of bei-passives in these two types of sentence structures across all the experimental groups. On the whole, almost all of the subjects were able to produce the grammatical sentences with both alternating and non-alternating unaccusative verbs in Category 2 and Category 3 without using the morpheme bei quite consistently.

ANOVA reveals that the differences of both the mean scores for Category 2: Non-alternating unaccusative verbs in the PD task are not statistically significant $(\mathrm{F}(2,59)=0.780, p=0.463)$ among the language groups of English and Chinese. ANOVA also reveals that the differences of the mean scores for Category 3: Alternating unaccusative verbs in the PD task are also not statistically significant (F (2, $59)=0.901, p=0.412$ ) among the language groups of English and Chinese.

In summary, only a few subjects in the four experimental groups overpassivized the non-alternating and alternating unaccusative verbs when cued to produce the sentences with either non-alternating or alternating unaccusative verbs in Categories 2 and 3 . This suggests that the phenomenon overpassivization of Chinese unaccusative verbs does not seem to be an acquisition problem for the L2 learners in our study regardless of their language backgrounds and language proficiency.

\subsubsection{The Grammaticality Judgment (GJ) Task}

Table 3 below presents the three groups' (including subjects from English and Chinese) mean scores and $\%$ of the target responses for the test structures in Category 1: Change-of-state unaccusative verbs with agent, Category 2: Non-altemating unaccusative verbs, agent-less, and Category 3: Alternating unaccusative verbs, agent-less in the GJ task.

Table 3. Mean scores (MS) of responses and \% of target responses (TR) for test structures in Category 1 (Changeof-state unaccusative verbs + bei + agent), Category 2 (Non-alternating unaccusative verbs + bei (agent-less), Category 3 (Alternating unaccusative verbs + bei (agent-less) in the GJ task

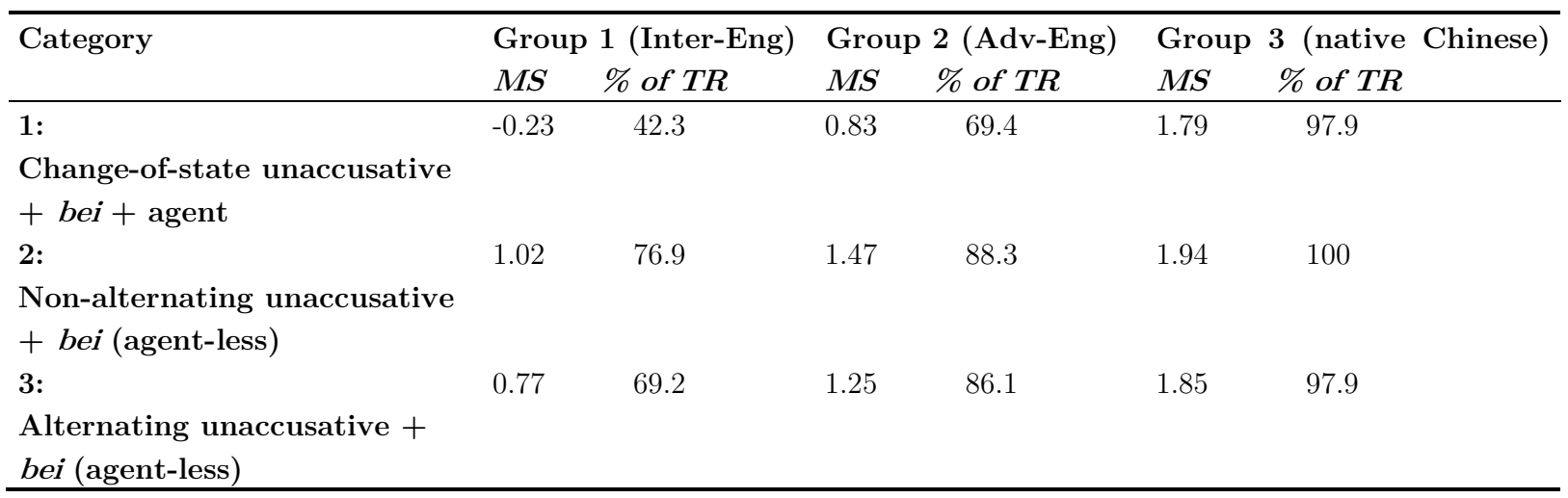

As can be seen from Table 3 above, the subjects from English-speaking groups (both intermediate and advanced levels) showed strong preference for the unaccusative type. Almost all of them were able to reject and correct the ungrammatical sentences with the two subtypes of unaccusative verbs (alternating and non-alternating) in Categories 2 and 3, by deleting the character 被 bei. They were able to reject passivized unaccusative verbs quite consistently (approximately $70 \%$ to $88 \%$ target responses for the two experimental groups).

However, the results show that the two experimental groups and even the controls performed better for the non-alternating unaccusative verbs than the alternating unaccusative verbs. All groups had higher percentages of target responses (i.e., rejected and corrected / deleted the ungrammatical 被 bei in the corresponding sentences) for the sentences in Category 2 (involving non-alternating unaccusative verbs) than the sentences in Category 3 (involving alternating unaccusaticve verbs). In fact, the English-speaking subjects in the two levels did not reject the ungrammatical 被 bei-passives. Though the advanced-level subjects (Group 2) performed better than the intermediate group (Group 1), their performance (69.2\% target responses) still fell short of the controls (97.9\% target responses). 
ANOVA reveals a significant difference for the mean scores for Category 1: Change-of-state unaccusative verbs in the GJ task among the subjects from the two languages $(\mathrm{F}(2,59)=16.612, p=$ 0.001). Post-hoc Scheffe test $(p<0.05)$ shows that these significant differences are found between the groups of the English-speaking learners and the controls.

ANOVA reveals that the differences of the mean scores for the structure in the GJ task, the differences are statistically significant $(\mathrm{F}(2,59)=5.523, p=0.006)$. The strictest Post-hoc Scheffe test $(p<0.05)$ indicates that these significant differences are found between the groups of the Englishspeaking learners and the controls.

ANOVA reveals that the differences of the mean scores for Category 3: Alternating unaccusative verbs in the GJ task are statistically significant $(\mathrm{F}(2,59)=6.819, p=0.002)$. The strictest Post-hoc Scheffe test $(p<0.05)$ indicates that these significant differences are found between the groups of the English-speaking learners and the controls. This indicates that alternating unaccusative verbs are subject to overpassivization more readily than non-alternating unaccusative verbs.

To conclude, the overpassivization problem of Chinese unaccusative verbs by L2 learners is only partially evidenced. While many English-speaking learners in the two levels tended to treat the changeof-state unaccusative verbs as transitive verbs, on the whole they did not overpassivize both the nonalternating and alternating unaccusative verbs in Category 2 and Category 3 in the GJ task.

\subsection{English-speaking L2 Learners vs. Controls}

In this section, the important findings regarding the performance of both intermediate and advanced level of English-speaking subjects in the two experimental tasks are combined and summarized for the sake of clarity. These findings are analysed in terms of the $\%$ of target responses, the percentage of some notable types of errors. The statistically significant differences of the mean scores for each test category by each experimental group (in each language proficiency level) will be also analyzed by Post-hoc Scheffe test wherever needed.

First, no difficulties were found for both the intermediate and advanced English-speaking learners when producing the sentences with the non-alternating and alternating unaccusative verbs in Categories 2 and 3. Both Group 1 and Group 2 could perform well in producing grammatical sentences with the alternating and non-altemating unaccusative without using the morpheme bei $(88.5 \%$ to $99 \%$ target responses). However, Group 1 had better performance for the alternating unaccusative verbs than the non-altemating unaccusative verbs. This is unexpected and different from the normal judgments by the other experimental groups.

Second, when judging the sentences in Category 2 (non-alternating unaccusative verbs) and Category 3 (alternating unaccusative verbs), the intermediate English-speaking subjects (Group 1) showed tendency to passivize the alternating unaccusative verbs. They had only $69 \%$ target responses and some of them (about 30\%) accepted the passivized form of the alternating unaccusative verbs with the morpheme bei and were not able to delete the ungrammatical bei from the sentences. Group 1 subjects performed better when judging the sentences in Category 2 (non-alternating unaccusative verbs), but their \% of target responses was not as high as that of the Group 2 (Group 1: $77 \%$ target responses and Group 2: $86 \%$ target responses). Statistically significant differences for the mean scores of the responses were indicated by Post-hoc Scheffe test $(p<0.05)$ between the groups of the intermediate Englishspeaking learners and the controls regarding both sentences with alternating or non-alternating verbs. There were not statistically significant differences for the mean scores of the responses in judging both sentences in Categories 2 and 3 between the advanced English-speaking subjects and the controls. In fact, these advanced English-speaking learners could perform quite native-like with over $86 \%$ target responses for the two categories of unaccusative verbs. On the whole, the performance of the two groups in the GJ task was not as well as that in the PDP task regarding ungrammatical 被 bei-sentences with either alternating or non-alternating unaccusative verbs.

Third, when judging the sentences in Category 1: Change-of-state unaccusative verbs, the Englishspeaking subjects, especially the intermediate English-speaking subjects, showed tendency to accept unaccusative verbs with the morpheme bei. Statistically significant difference was evidenced between Group 1 (42\% target responses) and Group 2 (69\% target responses) regarding the sentences in Category 1. Post-hoc Scheffe test $(p<0.05)$ also indicates that significant differences were found for the 
mean scores for Category 1 between the groups of the intermediate English-speaking learners and the controls.

\section{Discussion and Conclusion}

\subsection{The Research Question and Hypothesis}

For the ease of discussion, we repeat our research question and hypothesis as follows:

Research question:

Do L2 learners show a tendency to overpassivize unaccusative verbs in their Chinese IL?

Hypothesis of overpassivization of unaccusative verbs in Chinese:

Given the findings of many SLA studies that L2 learners of English regardless of LI backgrounds have tendency to overpassivize unaccusative verbs, even when advanced, we hypothesize that overpassivization phenomenon is a language universal in the IL development of learners of English, and we would expect to observe the same phenomenon occurring in the L2 acquisition of Chinese unaccusative verbs by English-speaking learners. If this hypothesis is correct, we should find evidence of overpassivization of unaccusative verbs in the learners' Chinese IL in our study. If overpassivization of unaccusative verbs is found in learners' Chinese IL, this may serve as evidence that the overpassivization of unaccusative verbs is a universal phenomenon in L2 acquisition regardless of the target languages and the language backgrounds of learners.

\subsection{A Summary of the Findings in the PDP Task and the GJ Task}

In the PDP task, only a few subjects in the two experimental groups (both intermediate-level and advanced-level subjects) overpassivized the alternating and non-alternating unaccusative verbs when cued to produce the sentences in Category 2 and Category 3. The overpassivization phenomenon of Chinese unaccusative verbs is not strongly evidenced in the production data of the L2 learners in our study regardless of their language backgrounds and language proficiency.

In the GJ task, while most subjects tended to accept passivized change-of-state unaccusative verb with agent as grammatical sentences and rejected passivized alternating and non-altemating unaccusative verbs, the intermediate English-speaking subjects consistently showed the poorest performance. These intermediate-level subjects show the weakest performance among the other groups for the sentences with passivized change-of-state unaccusative verbs (only $42.3 \%$ target responses), the sentences with passivized non-alternating unaccusative verbs (76.9\% target responses) as well as the sentences with passivized alternating unaccusative verbs (69.2\% target responses).

\subsection{Overpassivization of Chinese Unaccusative Verbs and the Universality of Overpassivization Phenomenon in IL Grammar}

While most subjects tended to accept passivized change-of-state unaccusative verb with agent as grammatical sentences and rejected passivized alternating and non-altemating unaccusative verbs, the intermediate-level subjects consistently showed the poorest performance. These intermediate-level subjects show the weakest performance among the other groups for the sentences with passivized change-of-state unaccusative verbs (only $42.3 \%$ target responses), the sentences with passivized nonalternating unaccusative verbs (76.9\% target responses) as well as the sentences with passivized alternating unaccusative verbs (69.2\% target responses). There is some evidence of overpassivization of Chinese unaccusative verbs in the results of the GJ task when the L2 learners were asked to judge the grammaticality of the test sentences in Category 1: Change-of-state unaccusative verbs, such as 我被收 音机醒了 Wo bei shouyinji xing le 'I was awaken by the radio', with only $42 \%$ to $69 \%$ target responses for the two experimental groups (controls: 98\% target responses). Not only the intermediate-level subjects but the advanced-level subjects also showed some tendency to accept the passivized unaccusative verbs in the GJ task. However, we suspect that the judgments might not be the result of 
overpassivization of Chinese unaccusative verbs and we will try to propose other possible accounts for the phenomenon in the last section of our study.

However, when asked to judge and produce the sentences with the alternating and non-alternating unaccusative verbs, almost all the subjects regardless of their proficiency level of Chinese showed preference for the non-passivized form of the unaccusative verbs (69\% to $98 \%$ target responses produced). In general, the advanced-level learners performed better than the intermediate-level learners. The intermediate-level learners performed the worst of all in regard to the test structures of unaccusative verbs in the GJ task. In fact, they showed some tendency to accept the passivization of the alternating unaccusative verbs as only $69 \%$ of their responses were target responses. Some of the intermediate English-speaking subjects (about 30\%) were not able to reject and delete the ungrammatical bei in the sentences. However, these subjects performed more native-like in the PDP task. In general, the subjects in our experiment, including the intermediate-level English-speaking learners of Chinese, did not produce passivied unaccusative verbs with 被 bei in the sentences with either the alternating or non-alternating unaccusative verbs.

In brief, based on the results of the experiment in our study, there is no strong or clear evidence for the overpassivization of Chinese unaccusative verbs by the English-speaking subjects. The learners regardless of their proficiency level performed poorly when judging the ungrammatical passivized form of the change-of-state unaccusative verbs. On the other hand, the advanced-level learners did not show strong tendency to produce passivized form of the unaccusative verbs in Categories 2 and 3 regarding the alternating and non-alternating Chinese unaccusative verbs. However, the learners generally performed better for the non-alternating unaccusative verbs than the alternating unaccusative verbs. Overall, the overpassivization of the unaccusative verbs is only shown clearly in the performance of the intermediate English-speaking subjects. The results mentioned above call into question the claim that the overpassivization of unaccusative verbs is universal in L2 acquisition (c.f. Ju 2000, p. 105). Further systematic investigations are necessary to address the issue with more concrete evidence.

\subsection{Conclusion}

By and large, the results of our experiment did not show clear evidence of overpassization of Chinese unaccusative verbs. While most subjects regardless of their proficiency level showed tendency to accept the ungrammatical passivized form of the unaccusative verbs in Category 1: Change-of-state unaccusative verbs, they in general were able to reject the passivized unaccusative verbs in Category 2 Non-alternating unaccusative verbs and Category 3: Alternating unaccusative verbs. As there is no strong evidence for the overpassivization phenomenon of Chinese unaccusative verbs by the Englishspeaking learners, this calls into question the claim that the phenomenon of overpassivization to unaccusative verbs is universal in L2 acquisition. The issue is still open for further investigations.

\subsection{Suggestions for Further Studies}

Based on the findings in our experiment, we suggest that further systematic investigations on the L2 acquisition of Chinese unaccusative verbs (both alternating and non-altemating) by learners from various language backgrounds should be conducted to address the issue of universality of overpassivization phenomenon in SLA.

Moreover, we note that the learners' divergent judgments (both intermediate-level and advanced-level English-speaking subjects) for the change-of-state unaccusative verbs in Category 1 and the other unaccusative verbs in Category 2 and Category 3 may be due to their incomplete knowledge of the lexicalized pattern of Chinese verbs. The unaccusative verbs we used in Category 1 are all simple (monosyllabic) unaccusative verbs, such as 醒 xing 'awake', 坏 huai 'break', 死 si 'die' , and 倒 dao 'fall' whereas the unaccusative verbs we used in Category 2 are mostly compound (disyllabic) unaccusative verbs, such as 出现 chuxian 'appear' and 消失 xiaoshi 'disappear'. In fact, some of the nonalternating unaccusative verbs in Category 2 are also change-of-state unaccusative verbs. However, there is a great divergence of learners' performance with regard to the unaccusative verbs in the two categories. One possible reason for this divergence is the learners' incomplete knowledge of Chinese verb compounds. Some learners, after the whole experiment, told us that they mistook 死si 'die', as 杀 sha 'kill' and accepted the passivized form of the verb with 被 bei, such as 那只老鼠被小猫死了 Nazhi 
laoshu bei xiamao si le '*That rat was died by the cat'. In fact, the change-of-state unaccusative verbs can only be treated as the resultatives in a sentence, and a transitive verb should be inserted to the sentence in front of the unaccusative verb to form the passive sentence. The learners who lack the proper knowledge of the lexicalized pattern of these verbs in Chinese failed to judge the sentences in Category 1 in a native-like manner.

Furthermore, the divergence of the performance of Category 1 and Categories 2 and 3 can be due to the differences between the long and short passives. The sentences in Category 1 are passives with agent NP while the sentences in Categories 2 and 3 are agentless passives (without agent NP). The learners in our study accepted passivized unaccusative verbs more frequently when an agent NP or causer was available than when it was not. This phenomenon is consistent with the findings of Ju (2000) who investigated whether conceptualizable agents in the discourse play a role in English L2 overpassivization errors. Ju (2002) hypothesized that the learners in his study transitivized unaccusative verbs before they passivized them and that the degree of transitization varies depending on the presence of conceptualizable agents in the discourse.

The overpassivization of the Chinese unaccusative verbs in our experiment can be accounted for by the hypothesis of non-target lexical causativization as in L2 acquisition of English (e.g., Balcom, 1997; Hirakawa, 1995; Ju, 2000; Montrul, 1999; Shomura, 1996; Yip, 1995). In our study, the learners performed better with non-alternating unaccusative verbs than alternating unaccusative verbs and this might suggest that learners were probably treating the alternating unaccusative verbs in our experiment as underlyingly transitive and thus accepted the ungrammatical passivized unaccusative verbs in the GJ task. This phenomenon is consistent with child's L1 development (e.g., Pinker, 1989). It is found that children's L1 acquisition of passive structures is greatly constrained by the transitivity of verbs. The earliest passive structures acquired by children are the passive structures with verbs of high degree of transitivity. Children might treat alternating unaccusative verbs as underlyingly transitive and in turn have the tendency to overpassivize them. As we did not test Category 1: Change-of-state unaccusative verbs in the PDP task, it is not clear whether the learners in our study would passivize these unaccusative verbs or not in their production. Thus, the transitivization hypothesis for the overpassivization phenomenon cannot be verified without learners' overpassivization data of the changeof-state unaccusative verbs in Category 1 in the PDP task.

In conclusion, further studies on the L2 acquisition of Chinese verb compounds can be carried out to shed light on the issues related to Chinese verb compounds and the lexicalized pattern of Chinese verbs. In addition, further investigations that focus on the acquisition of Chinese long and short passives (particularly the passives with or without an agent NP) can be carried out to further discuss the role of agent in the overpassivization of unaccusative verbs in SLA.

\section{References}

1. Balcom, P. (1997). What is happened? Passive morphology and unaccusative. Second Language Research, 13(1), $1-9$.

2. Burzio, L. (1986). Italian syntax: A grammar-binding approach. (Vol.1). Springer Science \& Business Media.

3. Chomsky, N. (1986). Knowledge of language: Its nature, origin, and use. Greenwood Publishing Group.

4. Hashimoto, M. (1987). Hanyu beidongshi de lishi quyu fazhan [The historical and geographical development of Chinese passive constructions], Zhongguo Yuwen 196, 36-49.

5. Hirakawa, M. (1995). L2 acquisition of English unaccusative construction. In Proceedings of the 19th Boston University Conference on Language Development, (Vol. 1, 291-303).: Cascadilla Press Somerville, MA.

6. Huang, C. T. J. (1999). Chinese passives in comparative perspective. Tsing Hua Journal of Chinese Studies 29(4), 423-509.

7. Huang, C. T. J. (2006). Resultatives and unaccusatives: A parametric view. Bulletin of the Chinese Linguistic Society of Japan 253, 1-43.

8. Ju, M. K. (2000). Overpassivization errors by second language learners: The effect of conceptualizable agents in discourse. Studies in Second Language Acquisition, 22(1), 85-111.

9. Kondo, T. (2005) Overpassivization in second language acquisition. International Review of Applied Linguistics in Language Teaching, 43(2), 129-161. 
10. Kong, S. (2018). Unaccusative and Unergative Verbs in L2 English. Journal of Chinese Linguistics 46(1), 199225.

11. Koopman, H. (1984). The syntax of verbs. Dordrecht: Foris Publications.

12. Levin, B. \& Rappaport Hovav, M. (1995). Unaccusativity: At the syntax-semantics interface. Linguistic Inquiry Monograph. Cambridge, MA: MIT Press

13. Li, A. Y. H. (1990). Order and consituency in Mandarin Chinese. Dordrecht: Kuluwer.

14. Mathieson, P. (2017). Secret agents and innocent patients: The mysteries of the English passive voice and its use (and misuse) in EFL writing in Japan. Journal of Pan-Pacific Association of Applied Linguistics 21(2), 1-13.

15. Montrul, S. A. (1999). Causative errors with unaccusative verbs in L2 Spanish. Second Language Research 15(2), 191-219.

16. Oshita, L. (2000). 'What is happened' may not be what appears to be happening: A corpus study of 'passive' unaccusatives in L2 English. Second Language Research 16(4), 293-324.

17. Perlmutter, D. (1978). Impersonal passives and the unaccusative hypothesis. Berkeley Linguistics Society 4, 157 189.

18. Pinker, S. (1989). Learnability and cognition: The acquisition of argument structure. Cambridge, MA: MIT Press.

19. Simargool, N. (2006). What's happening to what was happened. PASAA, 39, 49-72.

20. Sorace, A. (1993). Incomplete vs. divergent representation of unaccusativity in non-native grammars of Italian. Second Language Research 9(1), 22-47.

21. Su, D. (2008). Why Passivize the Nonpassivizable? Conceptual Space, Argument Structure and L1 Transfer in L2 Acquisition of English Unaccusatives. ProQuest.

22. Travis, L. D. (1984). Parameters and effects of word order variation (Doctoral dissertation, Massachusetts Institute of Technology).

23. Tsujimura, N. (2013). An introduction to Japanese linguistics. John Wiley \& Sons.

24. Wei, P. C. (1994). Guhanyu Beidonshide Fazhan yu Yanbian Jizhi. Chinese Languages and Linguistics 2, 293319.

25. Yip, V. (1995). Interlanguage and learnability: From Chinese to English. John Benjamins Publishing.

26. Zobl, H. (1989). Canonical typological structures and ergativity in English L2 acquisition. Linguistic Perspectives on Second Language Acquisition, 203-21.

\section{Appendix A:}

\section{Chinese Language Proficiency Test}

(Time allowed: 15 minutes)

Full Name (in English):

Date:

(in Chinese/Japanese):

Score:

Part I Grammar Task (Multiple-choice: 15 questions)

请在四个答案中圈出唯一恰当的答案。Please circle the best answer among the four.

1. 小明非常聪明, 从小 会做各种各样的玩具。
A 才 $\mathrm{B}$ 就 $\mathrm{C}$ 再 $\mathrm{D}$ 又

2. 请替我

以前的老师和同学问好。

$\mathrm{A}$ 往 $\mathrm{B}$ 向 $\mathrm{C}$ 把 $\mathrm{D}$ 给

3. 大卫昨天

踢足球去了, 却说自己去上课了。
$\mathrm{A}$ 明显
$\mathrm{B}$ 毕竞
$\mathrm{C}$ 明明
$\mathrm{D}$ 明白 
A 不管...就 $\quad$ B 哪怕...也 $\mathrm{C}$ 无论...都 $\mathrm{D}$ 既然...也

5. 对你们的看法我没 可说的。
A 怎么
B 那么
C 多么 D 什么

6. 今天晚上有舞会, 她们都打扮得 的。
$\mathrm{A}$ 漂亮
B 漂亮一漂亮
$\mathrm{C}$ 漂亮漂亮
$\mathrm{D}$ 漂漂亮亮

7. 这 电影的男主角是我的中学同学。
$\mathrm{A}$ 片 $\mathrm{B}$ 本 $\mathrm{C}$ 位 $\mathrm{D}$ 部

8. 外边雨不大, 拿雨衣 雨伞都可以。
$\mathrm{A}$ 还是
$\mathrm{B}$ 或者
C 还要
$\mathrm{D}$ 或许

9. 十年过去了, 我的愿望还是没 实现。
$A$ 会 $B$ 能 $C$ 肯 $D$ 要

10. 比赛 发生了一些意外。
$\mathrm{A}$ 上 $\mathrm{B}$ 里 $\mathrm{C}$ 中 $\mathrm{D}$ 下

11. 大卫希望以后能有机会 来中国。
A 更 B 才
C 再
D 又

12. 你妹妹已经十八岁了 $?$
$\mathrm{A}$ 喂 $\mathrm{B}$ 吗 $\mathrm{C}$ 呢 D 哪

13. 过了半个小时, 哥哥才慢慢 醒。
A 上来
$\mathrm{B}$ 过来
C 起来
D 过去

14. 请你
$\mathrm{A}$ 等我在学校门口下午三点。
$\mathrm{B}$ 等我下午三点在学校门口。
$\mathrm{C}$ 在学校门口等我下午三点。
$\mathrm{D}$ 下午三点在学校门口等我。

15. 姐姐的手里拿着
A一个大大红苹果。
B一个大大的红苹果。
$\mathrm{C}$ 红的大大一个苹果。
D一个红的大大苹果。

\section{Part II Cloze Passages}

\section{A. Multiple-choice (5 questions)}

请根据上下文的意思圈出唯一恰当的词语。Please read the passage and circle the best answer.

\begin{tabular}{|c|c|}
\hline $\begin{array}{l}\text { 大卫说一 } 16 \text { 流利的英语, 但中国话 } \\
\text { 根本 } 17 \text { 不会说。而我的英语只有中 } \\
\text { 学 } 18 \text {, 怎么应付得了? 没办法, 只 } \\
\text { 好通过 } 19 \text { 手势, 画图画来 }\end{array}$ & 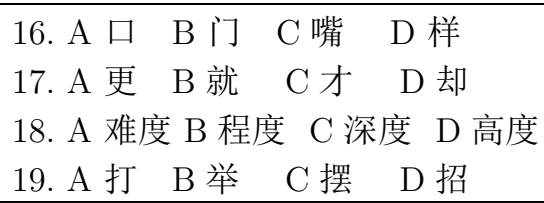 \\
\hline
\end{tabular}


20 思想。

20. A 交际 B 交流 C 交易 D 交往

B. Fill in the blanks ( 5 questions)

请根据上下文的意思在答卷的每一空格填写一个恰当的汉字。Please read the passage and insert ONE suitable Chinese character in EACH blank.

小英就要大学毕业了, 现在正在李教授的 21 .指

下写毕业论 文。在大学的四年里，小英都 很 22 . 真学习。老师们 22.普 认为, 她是一个不可多得的好学生。对自己的 24. 前 ，小英充满了 25 . 信。

谢谢您抽空完成这份卷子！Thank you for completing this test paper!

\section{Appendix B}

\section{Picture Description Production Task}

(Suggested time: 20 minutes)

Full Name:

Date:

(in Chinese/Japanese):

Score:

Please complete the following sentences, which describe the situations in the pictures, with the phrases provided. You CAN add other words if you feel necessary. You CAN also use Chinese Pinyin to write the sentences.

请用所给的词语完成下列各句来形容图片中的情况。如果您觉得有需要, 可加用其它字词来帮助您完成 句子。您也可用拼音完成句子。

\section{Example 例题}

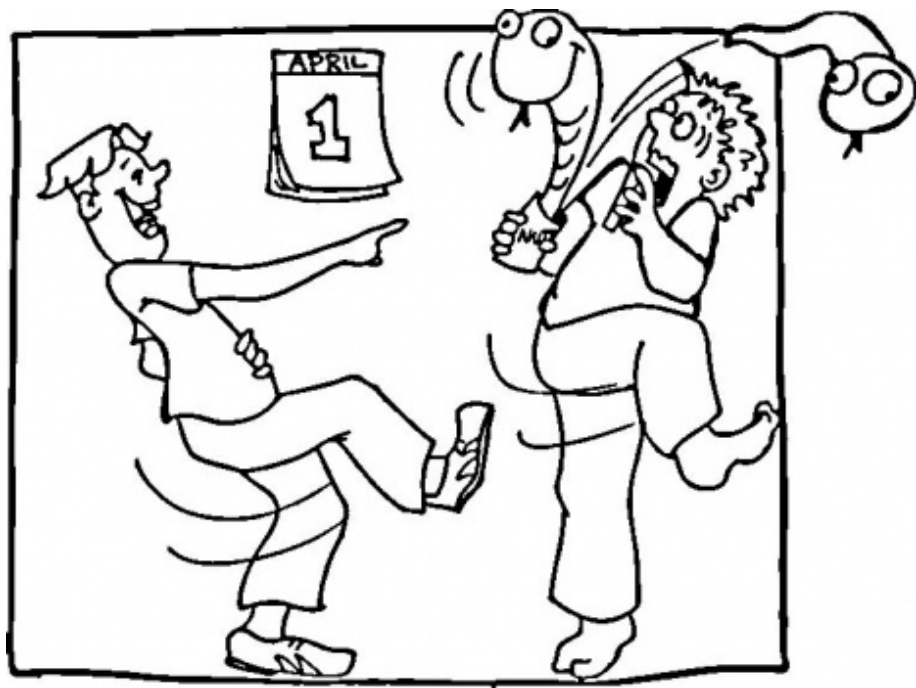

$\begin{array}{cccccc}\text { Tóngxué } & \text { le } & \text { shàngwù } & \text { dìdi } & \text { zhuōnòng } & \text { jīntiān } \\ \text { 同学 } & 了 & \text { 上午 } & \text { 弟弟 } & \text { 捉弄 } & \text { 今天 }\end{array}$




\section{弟弟今天上午被同学捉弄了。}

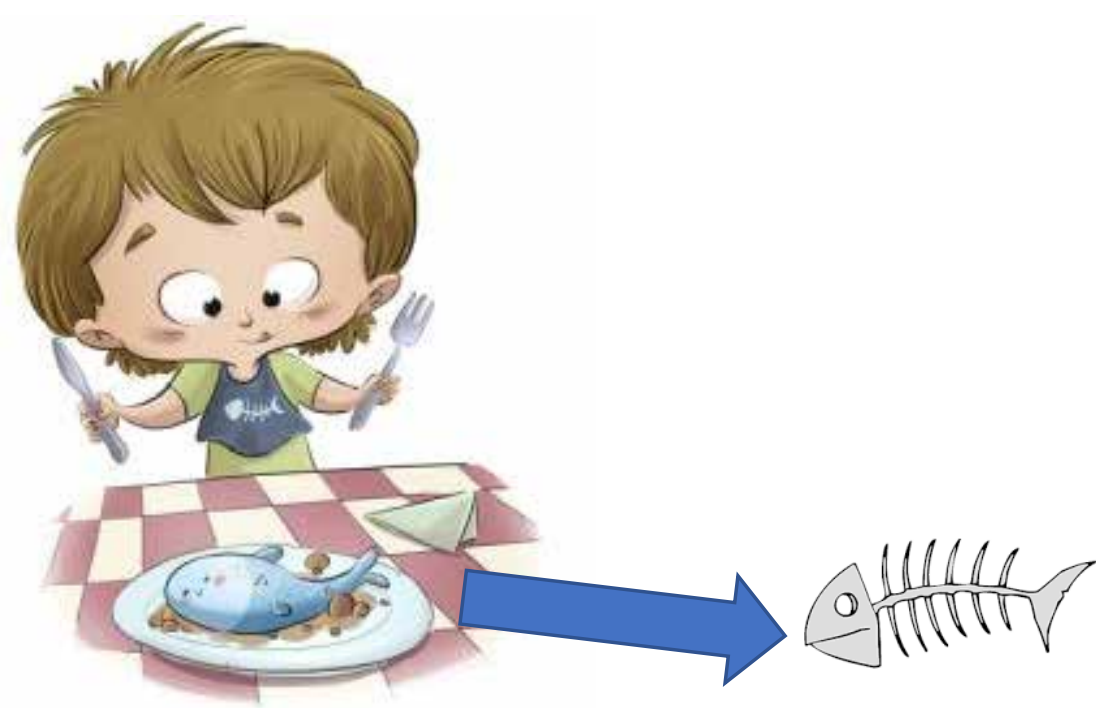

Gānggāng le chīdiào yú nàtiáo

刚刚了吃掉 鱼 那条

那条

\section{Appendix C}

\section{Grammaticality Judgement Task \\ (unrandomized version)}

请仔细阅读下列各句，并判断各句的表达方式是否正确。

Please read the following sentences carefully and then make a choice to judge the grammaticality of the sentences.

$\begin{array}{lcccc}-2 & -1 & 0 & 1 & 2 \\ \text { Incorrect 错 } & \text { not sure 不肯定 } & \text { correct 对 }\end{array}$

Category 1: Change-of-state uaccusative verbs

1. 我被收音机* (吵) 醒了。

2. 这台电视机被大卫* (弄) 坏了。

3. 那只老鼠被小猫* (咬) 死了。

4. 那些树被风* (刮) 倒了。

5. 那条手绢被小美* (哭) 湿了。

Category 2: Non-alternating unaccusative verbs

6. 等了很久, 小英终于 (*被) 出现了。

7. 太阳出来后, 浓雾渐渐 (*被) 消失了。

8. 那个小孩不小心 (*被) 跌倒了。 
9. 秋天来了, 很多树叶从树上 (*被) 掉了下来。

10. 妈妈非常担心, 头发 (*被) 愁白了。

\section{Category 3: Alternating unaccusative verbs}

11. 一场大雨后, 那块石头从山上 $(*$ 被) 滚下来了。

12. 这座木桥太旧了，上个月终于 (*被) 断了。

13. 汤冷了后, 味道很快（*被）改变了。

14. 什么都烧完了, 火就渐渐地 (*被) 灭了。

15. 因为温室效应, 北极的冰川开始 (*被) 融化了。 